\title{
THE ABUNDANCE OF ORNAMENTAL CORALS AFTER MASS DIE OFF IN 1997 ON THE PADANG SHELF REEF SYSTEM, WEST SUMATERA, INDONESIA
}

\author{
Ofri Johan ${ }^{1 *}$, Anjang B. Prasetio ${ }^{1}$, Idil Ardi ${ }^{1}$, Amran R. Syam ${ }^{2}$, and Norman J. Quinn ${ }^{3}$ \\ ${ }^{1}$ Research and Development Institute for Ornamental Fish Aquaculture, Depok \\ ${ }^{2}$ Research Center for Fisheries Management and Conservation, Purwakarta \\ ${ }^{3}$ Tropical Discoveries, Prescott-Arizona, USA; *E-mail: ofrijohan@kkp.go.id
}

\begin{abstract}
The Indonesian Ministry of Marine Affairs and Fisheries aims to establish export quota ornamental corals based on scientifically-founded data from the natural environment. The purpose of this study was to determine the abundance of ornamental coral after mass die off in 1997. Ornamental corals were classified into three groups based on the guideline of ornamental coral propagation for trading purposes. Classification categories are rapid (3-6 months), middle (8-12 months), and slow growth rate (>24 months), which relates to their harvesting time when transplanted for the trade purpose. The survey method used line intercept transects to get coral condition data and belt transect with $2 \mathrm{~m}$ width to get ornamental coral data. Both line and belt transect have $30 \mathrm{~m}$ length and with three replicates. The study showed number of colony and abundance of ornamental coral for fast growth rate group such as Acropora sp $\left(1348 \mathrm{col} \& 7.49 \mathrm{col} / \mathrm{m}^{2}\right)$, Galaxea sp, Hydnophora exesa, H. microconus, Pocillopora damicornis, Stylopora sp and Montipora sp with the highest abundant found on Acropora sp and Montipora sp $\left(1348 \mathrm{col} \& 7.49 \mathrm{col} / \mathrm{m}^{2}\right)$. Whereas the coral which from middle growth rate were Leptoseris sp, Pavona sp, Platygyra sp, Favia sp, Favites sp with the highest abundant found on Favia $\mathrm{sp}\left(101 \mathrm{col} \& 0.56 \mathrm{col} / \mathrm{m}^{2}\right)$. Coral species typically used for ornamental coral trade within the slow growth rate category such massive coral were not found on this survey. Due to the massive coral dieoff in 1997 and the paucity of ornamental corals, the utilization of ornamental coral should be supported by coral transplantation and the broodstock of slow growth of coral taken from other area.
\end{abstract}

Keywords: ornamental coral, abundant, mass die off, Padang Waters

\section{ABSTRAK}

Kementerian Kelautan dan Perikanan berharap dapat menyusun kuota ekspor karang hias berdasarkan data ilmiah yang diambil langsung dari alam. Tujuan dari penelitian ini adalah untuk menentukan kelimpahan karang hias serta karakteristik habitatnya setelah kematian massal pada tahun 1997. Karang hias diklasifikasikan ke dalam tiga kelompok berdasarkan pedoman dari propagasi karang hias dalam perdagangan berdasarkan lama pemiliharaa hingga pemanfaatan tujuan ekspor, yaitu kelompok pertumbuhan cepat (3-6 bulan), sedang (8-12 bulan) dan tingkat pertumbuhan lambat (> 24 bulan). Metode survei yang digunakan garis intercept transek untuk mendapatkan data kondisi terumbu karang dan sabuk transek dengan lebar $2 m$ untuk mendapatkan data karang hias. Kedua transek garis dan sabuk memiliki panjang $30 \mathrm{~m}$ dan dengan tiga ulangan. Hasil penelitian ini menunjukkan jumlah koloni dan kelimpahan karang hias untuk kelompok tingkat pertumbuhan yang cepat seperti Acropora sp $\left(1348 \mathrm{col} / \mathrm{m}^{2} \&\right.$ \& $\left.49 \mathrm{col} / \mathrm{m}^{2}\right)$, Galaxea sp, Hydnophora exesa, H. microconus, Pocillopora damicornis, Stylopora sp dan Montipora sp dengan kelimpahan tertinggi ditemukan paada Acropora sp dan Montipora sp $\left(1348 \mathrm{col} \& 7,49 \mathrm{col} / \mathrm{m}^{2}\right)$. Sedangkan karang yang dari tingkat pertumbuhan sedang ditemukan jenis Leptoseris sp, Pavona sp, Platygyra sp, Favia sp, Favites sp dengan kelimpahan tertinggi ditemukan pada Favia sp (101 col \& 0,56 col $\left(\mathrm{m}^{2}\right.$ ). Jenis karang yang biasanya banyak dimanfaatkan untuk perdagangan karang hias dari kategori pertumbuhan yang lambat atau karang polip besar dimana pada penelitian ini tidak ditemukan. Dampak dari kematian massal pada tahun 1997 belum terjadi pemulihan pada semua jenis karang sehingga pemanfaatan karang hias harus didukung oleh transplantasi karang dan perlu mendapatkan induk karang dari kelompok pertumbuhan lambat dari daerah lain.

Kata kunci: karang hias, kelimpahan, kematian masal, perairan Padang 


\section{INTRODUCTION}

Export of ornamental coral from Indonesia started in 1980. Since 2000, Indonesia has been the main exporter of ornamenttal corals in the world which had supplied about $70-80 \%$ to the global trade in live corals. It was about $91 \%$ international supply of ornamental coral market in 2008 (Timotius et al., 2009; Bentley, 1998; Mulliken and Nash, 1993; Bruckner, 2003). The coral quota for export from Indonesia in 2014 is 619.250 pieces (Suharsono, 2014). The United States, Japan and the member states of the European Union are currently the world's largest importers and consumers of aquarium corals (Green \& Shirley, 1999).

The most commonly species of ornamental corals which exported from Indonesia consisted colonies of branching (Acropora spp., Seriatopora spp. and Pocillopora spp.) with some of them has already from transplanted coral and fungiid coral (Fungia spp.), massive species (Favia spp., Favites spp., Goniopora spp.) and species with large fleshy polyps and prominent tentacles such as Euphyllia spp, Plerogyra sp, Cynarina lacrymalis, Catalaphyllia jardinei, Physogyra lichtensteini. (Green and Shirley, 1999, Wood et al., 2012).

Exporters have succeeded in culturing small polyp corals which rapid growth rate in several locations in Indonesia (Kepulauan Seribu, Banten, Bali, Kendari) such as Acropora spp., Montipora spp., Seriatopora spp., so the numbers exported from the wild has declined both harvest quota and export quota from 2006 (855,500 and 797,316 pieces) to 2014 (619,250 and 619,250 piece) (Suharsono, 2014). There is still a large demand for large polyp corals which collected from the wild due to the unsuccessful from the transplantation source, the study of transplantation for large polyp coral is still in progress. CITES (Convention for the International Trade in Endangered Species of Wild Fauna and Flora) regulate international trade to ensure that coral trade is not threatening wild populations.

All scleractinian corals (stony corals) are currently listed on Appendix II and six coral species are completely banned under EU specific legislation: Montipora caliculata, Catalyphyllia jardinei, Plerogyra spp., Blastomussa spp, Cynarina lacrymalis, Trachyphyllia geoffroyi (Koldewey and Jones, 2007). Several of these corals were found on Padang Shelf Reef System in 1994 such as Australomussa rowleyensis, Cynarina lacrymalis, Lobophyllia spp, Symphyllia spp, Echinopora horrida, E. lamellose, Euphyllia glabrescens, Physogyra lictensteini and Plerogyra sinuosa (Jonker and Johan, 1999). These species have slow growth and uncommon found in the wild or with low population densities (Best, 2002; Wood et al., 2012).

In addition, these species are coral trade target with high economic value whether in domestic or international trade, so that locally often over-collected which gave bad impact on their population due to overfishing in all coral reef regions of the world (Koldewey and Jones, 2007; Best, 2000; Timotius et $a l, 2009)$. Exports of Appendix II listed species require permits from the exporting countries that state that the export will not be detrimental to the survival of the species or its role in the environment. In Padang waters happened mass coral die of due to the bleaching event in 1997 and recorded 0\% life coral cover in 1998 (Jonker and Johan, 1999). This condition made most ornamental corals died together with all corals in this area.

This survey was carried out after 17 years the coral mass die off in this area. It is important to know the current condition of coral and the abundant of ornamental corals. Moreover, the study of ornamental coral abundance is rare carried out in Indonesia, moreover the quota is not set up according to real data of the wild stock but it was based on the export realization last year for the next year quota. The hypothesis of this research was coral condition and the abundant of ornamental coral were already recovered 17 
years since the coral died happening. The purpose of this research was to investigate the coral condition and abundance of ornamenttal coral in Padang Shelf Reef System waters, since the impact of the mass coral die off in 1997 and other degradation factors before this event (Kunzmann and Efendi, 1994). Presently, there is no catching quota from West Sumatera. The future, ornamental coral should be from propagation result.

\section{METHODS}

\subsection{Research Sites}

Abundance of ornamental coral research was carried out in early of May 2014 at 6 sites of permanent transects which belong of 3 patch reefs and 3 islands as rep- resentative of inshore (Pisang Island, Gabuo patch reefs), mid-shore (Sipakal and Air patch reefs) and off-shore (Pandan and Pieh Islands). Permanent transect already established in 1995 as a program of COREMAP (Coral Reef Rehabilitation and Management Program).

The location position according to Geographical Position System (GPS) as following; at Pisang Island (0059'49.0'S, $100^{\circ}$ 20'19.9' E) and Gabuo patch reefs (00 $54^{\prime}$ 34.3'S, $\left.100^{\circ} 20^{\prime} 2.7^{\prime \prime} \mathrm{E}\right)$ as inshore sites, Air $\left(00^{\circ} 52^{\prime} 40.3\right.$ 'S, $100^{\circ} 05^{\prime} 55.7^{\prime \prime}$ E) and Sipakal patch reefs $\left(00^{\circ} 55^{\prime} 39.4^{\prime \prime} \mathrm{S}, 100^{\circ} 15^{\prime} 3.2^{\prime \prime} \mathrm{E}\right)$ as mid-shore sites, and Pieh (0052'39.7'S, $\left.100^{\circ} 05^{\prime} 57.5^{\prime} \mathrm{E}\right)$ and Pandan Island ( $00^{\circ} 57^{\prime}$ 11.2"S, $\left.100^{\circ} 08^{\prime} 15.1^{\prime \prime} \mathrm{E}\right)$ as off-shore sites.

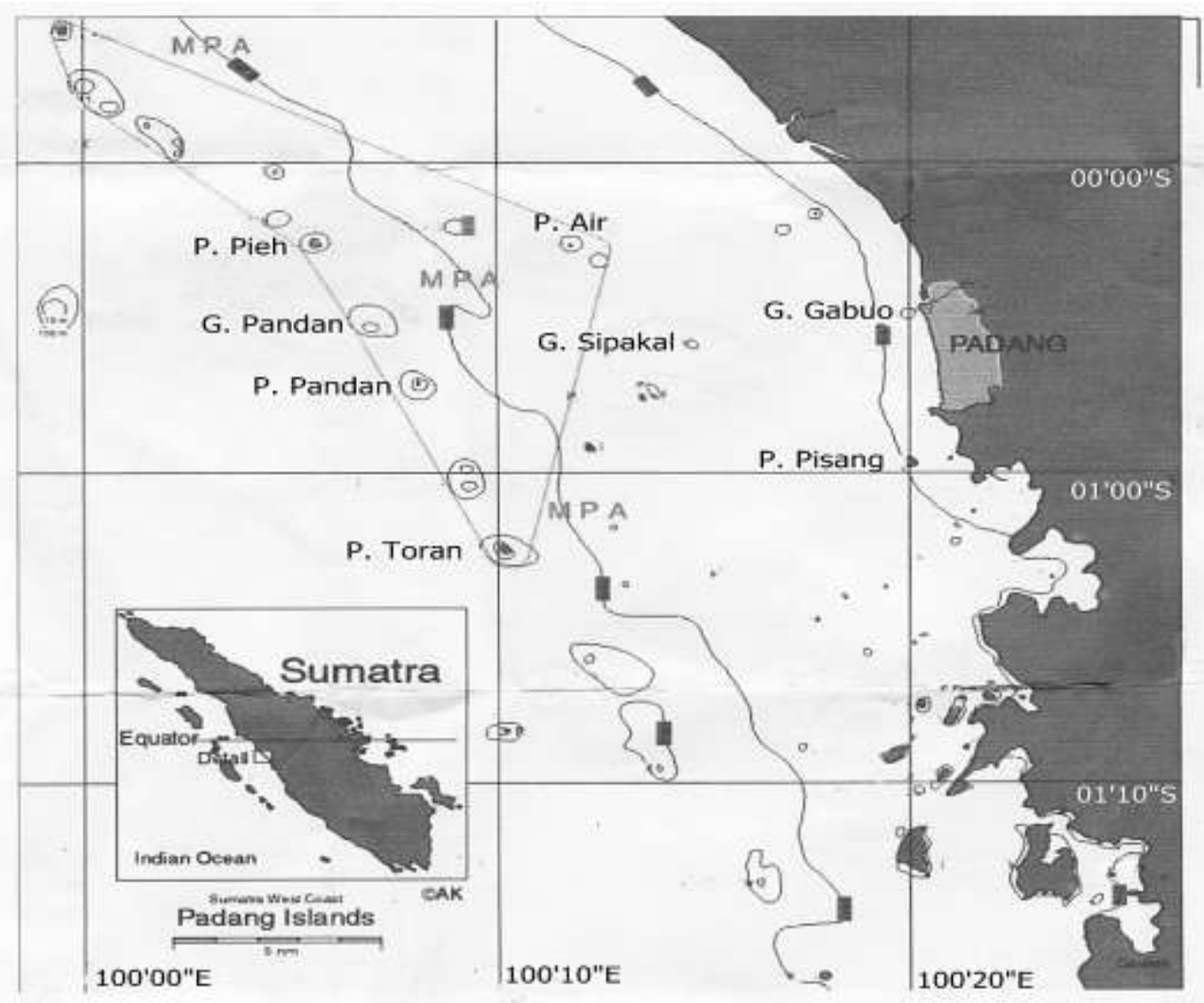

Figure 1. Padang Shelf Reef System with Marine Protected Area termed Marine Tourism Park and sampling sites indicated (modified after Kunzmann, 1997). Inshore sites (G. Gabuo and P. Pisang), mid-shore (G. Air and G. Sipakal) and off-shore (P. Pieh and P. Padan). $\mathrm{G}$ is patch reefs and $\mathrm{P}$ is Island. 


\subsection{Data Collection and Analyses}

The line intercept transects (LIT) which was used to get coral condition data, were signed by iron stick at each 10 meter length and renew when the monitoring carried out to keep the precise site for next survey. Whereas, the belt transect which was used to get data of ornamental corals abundance, carried out at the same location with LIT place with $1 \mathrm{~m}$ left and right of tape as long $30 \mathrm{~m}$ with 3 replications, so total area surveyed was $180 \mathrm{~m}^{2}$ on each site. Especially in Pandan, Pieh were collected data in $5 \mathrm{~m}$ and $10 \mathrm{~m}$ depth, other sites were unrepresentative to record coral data on both depths due to it was covering by sand or silt especially on $10 \mathrm{~m}$. The sites are presented at Figure1.

The other research method was carried out by using belt transect method. There was space about $5 \mathrm{~m}$ among transects of both LIT and belt transect. The site at Pieh and Pandan island were carried out 2 depth in 5 $\mathrm{m}$ and $10 \mathrm{~m}$. Data collection based on English et al. (1997). Each colony of coral was recorded by counting the number of colony, the scientific name of coral till species or genus level, then classified to be target species of coral trade and others which common found on that locations.

The ornamental corals is classified into 3 group based on regulation of General Directorate conservation of natural and forestry, number SK.09/IV/Set-3/2008, as followed rapid growth with 3-6 months of propagation age before exporting, middle growth date with 8-12 months of propagation age before exporting and slow growth rate with more than 24 months of propagation age before exporting.

The coral condition on location of ornamental study based on life coral coverage was investigated with line intercept transect (LIT) with recording the life form to know the percentage of life coral cover and coral genera with 29 criteria such as Acropora Branching (ACB), Coral Branching (CB), Coral Massive (CM), Coral Encrusting
(CE), Coral Folious (CF), Coral Mushroom (CMR), etc. (English et al., 1997).

Life coral coverage is classified to be best coral condition ( $75 \%$ to $100 \%$ ), good ( 50 to $<75 \%)$, bad ( 25 to $<50 \%$ ) and very bad condition ( 0 to $<25 \%)$ according to Gomez and Yap (1984).

\section{RESULTS AND DISCUSSIONS}

\subsection{Results \\ 3.1.1. Coral Condition on Ornamental Co- ral Sites}

The research on 6 permanent transects about coral condition according to life coral percentage, found the highest life percentage on Air patch reefs was $65,6 \%$ which classified as a good condition base on Yap and Gomes (1984). Average of life coral cover at other sites found the higher on midshore $(47.84 \% \pm 22.52)$, then follow with inshore $(41.65 \% \pm 7.81)$ and the lower at offshore (38.28\% $\%$ 7.79). Coral condition found only good condition in Air patch reefs, other sites were classified in bad condition.

\subsubsection{Ornamental Coral}

Research on 6 sites found 18 genera which some of them were ornamental coral as list on Table 1. Ornamental corals found 2 group which are rapid growth and mid rapid growth. The five most abundance of ornamental coral from rapid growth found as followed; Montipora sp, Acropora sp in Pisang Is., Pocillopora damicornis in Pisang Is., $P$. verrucosa in Pandan Is. and Cyphastrea sp. Other species with low abundance found are Hynophora sp, Leptoseries sp, Fungia sp and Stylopora sp as shown on Table 1 and Figure 2.

Whereas the five most abundance of ornamental coral from mid-rapid found as follow; Porites sp in Pandan Is. Goniastrea sp in Pandan Is., Galaxea sp in Gabuo patch reefs, Favia sp in Pandan Is. and Favona sp in Pieh Is. Other species also found with low abundance such as Platygyra sp, Psammocora $\mathrm{sp}$ and Favites $\mathrm{sp}$, as shown on Table 1 
Table 1. Abundance of ornamental coral in Padang Shelf Reef System (col. $\left.\mathrm{m}^{-2}\right)$.

\begin{tabular}{clrrrrrr}
\hline No & Genus & G. Gabuo & \multicolumn{1}{c}{ Pisang } & \multicolumn{1}{c}{ G. Air } & \multicolumn{1}{l}{ G. Sipakal } & \multicolumn{1}{c}{ Pieh } & \multicolumn{1}{c}{ Pandan } \\
\hline 1 & Montipora sp & $1.36 \pm 0.54$ & $2.89 \pm 0.01$ & $0.00 \pm-$ & $0.75 \pm 0.10$ & $0.42 \pm 0.08$ & $0.82 \pm 0.20$ \\
2 & Acropora sp & $0.26 \pm 0.08$ & $1.04 \pm 0.23$ & $0.32 \pm 0.04$ & $0.80 \pm 0.10$ & $0.54 \pm 0.11$ & $0.62 \pm 0.07$ \\
3 & Porites sp & $0.01 \pm 0.00$ & $0.00 \pm-$ & $0.52 \pm 0.15$ & $0.16 \pm 0.03$ & $0.47 \pm 0.09$ & $0.70 \pm 0.14$ \\
4 & Pocillopora verrucosa & $0.00 \pm 0.01$ & $0.00 \pm 0.01$ & $0.10 \pm 0.02$ & $0.16 \pm 0.03$ & $0.34 \pm 0.07$ & $0.43 \pm 0.17$ \\
5 & Pocillopora damicornis & $0.27 \pm 0.08$ & $1.24 \pm 0.46$ & $0.07 \pm 0.03$ & $0.02 \pm-$ & $0.01 \pm-$ & $0.06 \pm 0.02$ \\
6 & Goniastrea sp & $0.01 \pm 0.00$ & $0.00 \pm-$ & $0.29 \pm 0.04$ & $0.06 \pm 0.01$ & $0.07 \pm 0.06$ & $0.30+0.03$ \\
7 & Galaxea sp & $0.32 \pm 0.18$ & $0.12 \pm 0.04$ & $0.02 \pm 0.01$ & $0.01 \pm-$ & $0.02 \pm 0.01$ & $0.03 \pm 0.01$ \\
8 & Favia sp & $0.08 \pm 0.03$ & $0.03 \pm 0.01$ & $0.03 \pm 0.02$ & $0.07 \pm 0.01$ & $0.05 \pm 0.02$ & $0.13+0.02$ \\
9 & Cyphastrea sp & $0.02 \pm 0.01$ & $0.04 \pm 0.01$ & $0.07 \pm 0.02$ & $0.04 \pm-$ & $0.09 \pm 0.04$ & $0.07 \pm 0.02$ \\
10 & Hydnophora microconus & $0.00 \pm-$ & $0.00 \pm-$ & $0.05 \pm 0.01$ & $0.04 \pm 0.01$ & $0.09 \pm 0.02$ & $0.05 \pm 0.01$ \\
11 & Pavona sp & $0.01 \pm 0.00$ & $0.01 \pm 0.01$ & $0.06 \pm 0.02$ & $0.00 \pm-$ & $0.09 \pm 0.04$ & $0.06 \pm 0.01$ \\
12 & Psammocora sp & $0.07 \pm 0.02$ & $0.01 \pm 0.01$ & $0.00 \pm-$ & $0.00 \pm-$ & $0.03 \pm 0.01$ & $0.08 \pm 0.04$ \\
13 & Platygyra sp & $0.01 \pm 0.00$ & $0.02 \pm 0.01$ & $0.05 \pm 0.01$ & $0.02 \pm 0.01$ & $0.08 \pm 0.02$ & $0.02 \pm-$ \\
14 & Leptoseris sp & $0.00 \pm 0.02$ & $0.00 \pm 0.02$ & $0.13 \pm 0.06$ & $0.00 \pm-$ & $0.02 \pm 0.01$ & $0.03 \pm 0.01$ \\
15 & Favites sp & $0.00 \pm 0.00$ & $0.00 \pm 0.01$ & $0.07 \pm 0.01$ & $0.00 \pm-$ & $0.01 \pm 0.01$ & $0.02 \pm-$ \\
16 & Astreopora sp & $0.00 \pm-$ & $0.00 \pm-$ & $0.01 \pm 0.01$ & $0.02 \pm-$ & $0.003 \pm-$ & $0.011 \pm 0.01$ \\
17 & Fungia sp & $0.01 \pm 0.01$ & $0.02 \pm 0.01$ & $0.01 \pm 0.01$ & $0.01 \pm 0.01$ & $0.00 \pm-$ & $0.003 \pm-$ \\
18 & Stylopora sp & $0.00 \pm-$ & $0.00 \pm-$ & $0.00 \pm-$ & $0.00 \pm-$ & $0.00 \pm-$ & $0.01 \pm 0.01$ \\
19 & Ctenactis p & $0.01 \pm 0.00$ & $0.00 \pm-$ & $0.00 \pm-$ & $0.00 \pm-$ & $0.00 \pm-$ & $0.00 \pm-$ \\
20 & Hydnophora exesa & $0.00 \pm-$ & $0.00 \pm-$ & $0.00 \pm-$ & $0.00 \pm-$ & $0.003 \pm-$ & $0.00 \pm-$ \\
\hline
\end{tabular}

Note: \pm - indicates no replicate of the data (no standard deviation).
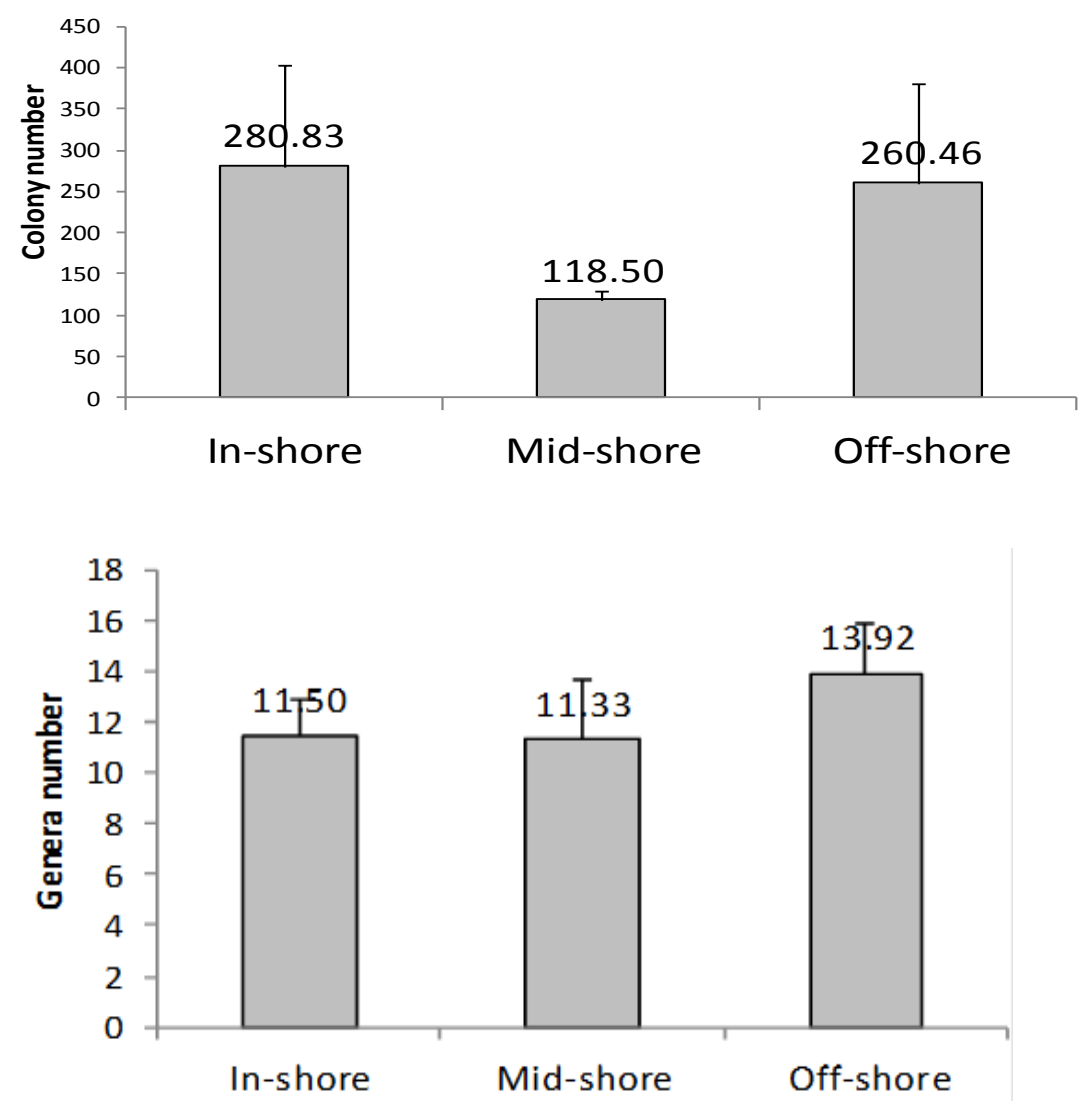

Figure 2. Total colony number (above) and genera number (bottom) of corals found in research site groups. 
and Figure 2. Colony number and the abundance of Favia sp (101 \& 0.56), Favites sp (23 \& 0.13), Galaxea sp (104 \& 0.58), Pavona sp (69 \& 0.38), Platygyra sp (52 \& 0.29 ). These kinds of ornamental coral is often ordered by consumer and transplanted by some exporters now in Indonesia.

Total colony number found the highest on in-shore than off-shore mid-shore sites, whereas genera number found the highest on the off-shore than in-shore and mid-shore sites. Colony number and genera number were negative correlation with life coral cover which the highest found in midshore sites. Total colony number and the genera number shown on Fig. 2.

Coral species of Montipora sp and Acropora sp which sensitive to high turbidity and sediment were found more abundance on the inshore (Gabuo patch reefs and Pisang Island), whereas these species were less abundance on the mid-shore and off-shore (Table 1).

The dissimilarity analysis of abundant coral on $20 \%$ found three groups among
Acropora sp and Porites sp (group 1), Montipora sp and group 1 as group 2, and others genera as group 3. The abundance of Montipora sp is the highest of dissimilarity (26\%), meanwhile there were the same dissimilarity between Acropora sp and Porites sp (6\%), Pocillopora damicornis and Hydnophora exesa (3\%), and Pocillopora verrucosa and Goniastrea sp (2\%) among research locations as shown on Fig. 4.

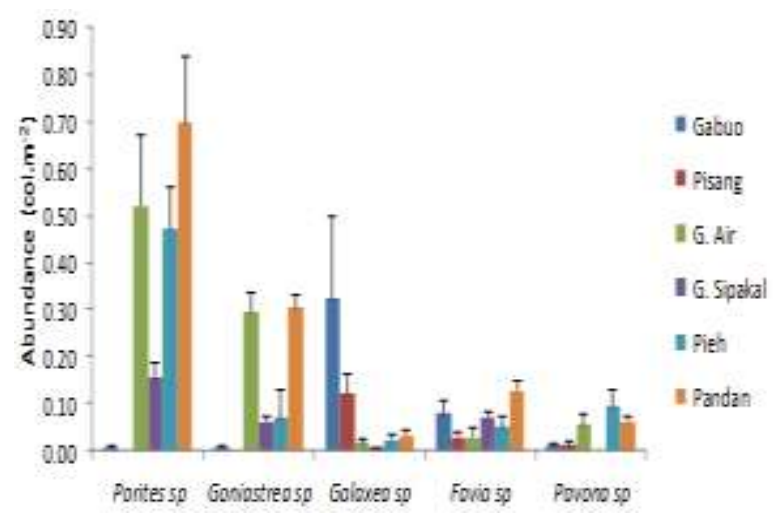

Figure 3. Ornamental corals abundance from middle growth rate group.

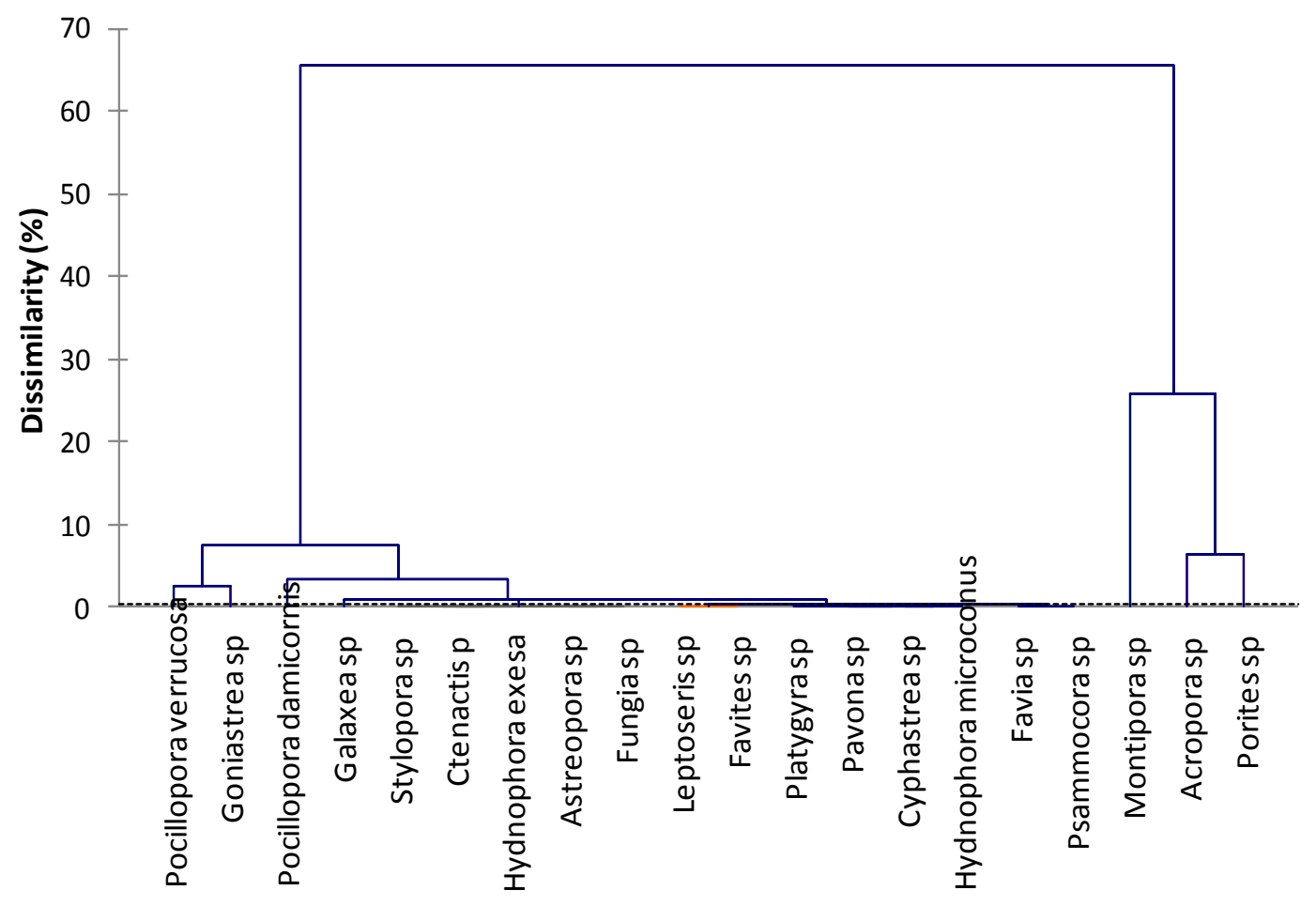

Figure 4. Dissimilarity abundance of genera/species of coral on all sites. 
Ornamental coral which found in Padang was widely distributed, it is not patchy or dominant on a specific place for a species as shown on Table 1, it was different with the species of large polyps coral such as Caulastrea sp, Euphyllia divisa in Lampung, Catalaphyllia jardinei on Padea Island in South-East of Sulawesi that they were found patchy and dominant on specific place (Johan, 2002; Turak et al., 2008). Mostly coral trade target which have large polyps and extend their tentacle were found on deep water and the substrate characterized by sand to silt (Johan et al., 2007).

The preferred, high value ornamental coral were not found in Padang water during the survey, whereas Jonker and Johan, (1999) reported some of these species collected from this area such as Australomussa rowleyensis, Cynarina lacrymalis, Lobophyllia spp, Symphyllia spp, Echinopora horrida, E. lamellose, Euphyllia glabrescens, Physogyra lictensteini and Plerogyra sinuosa. These species was usually found patchy such as Caulastrea sp, Euphyllia glabrescens and Trachyphyllia geffroyi in Lampung, E. ancora in Rembang, Catalaphyllia jardinei in Padea, Central Sulawesi (Johan, 2002).

\subsection{DISCUSSION}

Ornamental coral which found in Padang was classified to be two group based on captivity/transplantation of coral guideline stated on Directorate Genderal Decree of PHKA Number 09 in 2008 (PHKA, 2008). There were rapid growth rate with harvest time 3-6 months such as Acropora sp, Hydnophora sp, Pocillopora sp, Montipora sp dan Stylophora pistillata and the middle harvest time between 8 and 12 month such as Galaxea sp, Favia sp, Favites sp, Platygyra sp dan Goniastrea sp. whereas the slow growth rate for more 2 years harvest time of ornamental coral was not found during the survey.

Coral condition in Padang waters is recovering process, Air patch reefs is the best location now and better than it condition in 1994 according to life percentage coral cover. Although the best location in 1994 on Pieh Is. was not full recovery yet, coral were mass die-off caused the slow growth rate group of coral were not found yet on the six permanent transect sites, it could be due to a limited larvae sources and no mature coral or no successful recruits of these corals after the 1997 mass drowning coral. According to Jonker and Johan (1999), large polyp coral such as Australomussa rowleyensis, Cynarina lacrymalis, Lobophyllia spp, Symphyllia spp, Echinopora horrida, E. lamellose, Euphyllia glabrescens, Physogyra lictensteini and Plerogyra sinuosa were found in the Padang Shelf Reef System and its surroundding waters in the early 1990s. Mostly of these corals is distributed widely in Indonesia and can be found from the reef flat to the reefs slope. Some of them usually are hiding under other coral such Cynarina lacrymalis (Johan, 2002). The slow growth corals were not found due to the source larvae is limited caused of most coral drown in 1997 and the growth is take a long time. Coral species was not full recovery after 17 years.

The slow growth rate group is mostly classified as ornamental coral and moreover as target trade. The coral can be classified to ornamental coral when it has colorful and good performance. One species of coral could be has varies color. Although the coral species has classified on ornamental coral, if the species is not colorful there are less order from the consumer. Therefore one species of coral has different prize. The more colorful will be more expensive and more order.

Collection area of ornamental coral should be had life percentage cover more than $30 \%$ to guaranty the sustainable use based on the agreement paper of sustainable use of ornamental coral in Indonesia. Nevertheless, West Sumatera is not a place for collecting area of ornamental coral which declared by SA (Scientific Authority) and MA (Management Authority). Every year government declared how much colony and 
what province could be allowed to collect coral for ornamental. According the survey, the kind of ornamental coral which found in Padang waters were not a target species which has high prize. The current government regulation that forbidden to get ornamental coral from West Sumatera, are not negotiable. Other alternative, ornamental coral could be from aquaculture, but the brood stock should also come from outside area especially for the high target of ornamental corals species.

Suharsono and Giyanto (2006) suggested knowing the potential of ornamental coral for harvesting at any place should be record data of coral coverage, number of occurrence, genera dominance and size of colony. Through this data calculate to get total value which has range as abundance category such as very common, common, uncommon, rare and very rare.

Souvenir Collections

The collection of coral for souvenirs was considered an important threat to the reefs (Efendi and Sayarif, 1995; Kunzmann, 2000). In 2014, during a holiday weekend there was only a single vendor at the popular beach Air Manis, near Padang selling $20 \mathrm{~cm}$ wide Pocillopora verrucosa skeletons which were mostly collected from the beach wash. The vendor was asking for Rp120,000 Rp150,000 (August 3, 2014 US $\$ 1=$ Rp 11, $700)$ for the 14 corals. The vendor was observed for a 30 minute period during which there were four inquiries and no sales.

The prices are likely to be on the high end of the range since they were obtained by a foreigner (N.J.Q.) and he was charged double $(\mathrm{Rp} 10,000)$ the normal entrance fee $(\mathrm{Rp5}, 000)$ for the park. The fee was to pay for the "Padang Baywatch" team. A truck labeled "Badan Nasional Penanggulangan Bencana" drove along the beach with park rangers with a bright orange shirt and equipped with radios stationed along the beach. It was not clear whether their function was to rescues swimmers or enforces some management rules.

\section{CONCLUSIONS}

Ornamental coral in Padang waters only found species of rapid growth and middle growth rate, but it was not found the large polyp as a target species on coral trade in six sites permanent transect. The government regulation which does not include West Sumatera as ornamental collecting area is already suitable with the condition of a wild stock which not found the target species. Ornamental coral should be from propagation especially the middle growth rate and slow growth rate. The broodstock of slow growth rate can be from the other province which has a catch quota of the target bloodstock.

\section{ACKNOWLEDGEMENTS}

The authors would like to thank to the American Fulbright Fellowship for the funding on this survey, Minang Bahari staffs who support in dive equipment preparation and all team who supporting the survey in Padang. We would also like to express our gratitude to unanimous reviewers who provided criticism and comment to improve this paper.

\section{REFERENCES}

Abram, N.J., M.K. Gagan, M.T. McCulloch, J. Chappell, and W.S. Hantoro. 2003. Coral reef death during the 1997 Indian Ocean Dipole linked to Indonesian wildfires. Science, 301:952955.

Anonim. 2008. Pedoman penangkaran/ transplantasi karang hias yang diperdagangkan. Peraturan Direktur Jenderal Perlindungan Hutan dan Konservasi Alam No:SK.09/IV/Set-3/2008. 34hlm.

Best, B.A. 2000. Trade in coral reef animals, algae and products: an overview. Trade and management. The $9^{\text {th }}$ International Coral Reef Symposium. Bali, Indonesia. 73-77pp. 
Best, B.A. 2002. Coral reef in crisis: trade in coral reefs animals and products. Tropical Coast., 9(2):4-11.

Efendi, Y. and S.M. Syarif. 1995. Pengaruh aktivitas manusia terhadap kehidupan terumbu karang. Fish. J. Garing, 4 (2):47-54.

English, S., C. Wilkinson, and V. Baker. 1997. Survey manual for tropical marine resources, 2nd edn. Australian Institute of Marine Science, Townsville. 368 p.

Gomez, E.D. and H.T. Yap. 1984. Monitoring reef condition. In: Kenchington, R.A. and B. Hudson (eds.). Coral reef management hand book. Unesco Regional Office for Science and Technology for South East Asia. Jakarta. $171 \mathrm{p}$.

Green, E. and F. Shirley. 1999. The global trade in coral. World Conservation Press. WCMC, United Kingdom. 70p.

Johan, O. 2002. Stock assessment karang hias di Kendari. Research report. Collaboration with Indonesian association of coral, shells, and fish ornamental and Indonesian coral reefs working group. $40 \mathrm{hlm}$.

Johan, O., A. Budianto, and B. Priono. 2007. Studi tentang hubungan antara jenisjenis karang hias dengan karakteristik habitat di beberapa lokasi di Indonesia. Prosiding Seminar Nasional Kelautan III. Universitas Hang Tuah, Surabaya. Hlm.:37-42.

Johan, O., A. Priyadi, W. Hadie, R. Ginanjar, and Nurhidayat. 2014. Survei potensi dan identifikasi sumberdaya ikan hias dan karang hias laut di Kabupaten Belitung Timur. Balai Penelitian dan Pengembangan Budidaya Ikan Hias, Depok. 57hlm.

Jonker, L., and O. Johan. 1999. Checklist of the scleractinian coral species from the waters of Padang (West Sumatera, Indonesia) held in the coral collection of Bung Hatta University. The Beagle, records of the Museums and
Art Galleries of the Northern Territory, 15:47-54.

Klein, H., and A. Kunzmann. 2001 Strömungs messungenwestlich von $\mathrm{Pa}$ dang, Sumatra. Interner Bericht BSH (Bundesamt für Seeschiffahrt und Hydrographie, Hamburg 11.12.2001). $23 p$.

Koldewey, H., R. Jones. 2007. Life guard, working with HM customs to improve CITES enforcement for corals, clams and seahorses. Life Lines, 95:14.

Kunzmann, A. 2000. Marine ecosystems of West Sumatra. In: C. Sheppard (ed.) Seas at the millennium: an environmental evaluation. Vol. 2. Regional chapters, the Indian Ocean to the Pacific. Pergamon, Amsterdam. 368387pp.

Kunzmann, A., Y. Efendi. 1994. Kerusakan terumbu karang di perairan sepanjang pantai Sumatera Barat. J. Penelitian Perikanan Laut, 91:48-56.

Mulliken, T. and S. Nas. 1993. The recent trade in Philipine corals. TRAFFIC Bulletin, 13(3):97-105.

Raymeker, C. 2003. Monitoring of and quota setting for trade in live corals in Indonesia and Fiji. Traffic Europe (WWF Belgium). 45p.

Suharsono. 2014. Status dan kebijakan perdagangan karang hias untuk menjamin kelestarian dan kesejahteraan Masyarakat. Seminar Ikan Hias, Jakarta. $40 \mathrm{hlm}$.

Suharsono and Giyanto. 2006. A formulation approach to quantify the abundance of coral genera. Mar. Res. Indonesia., 31:1-11.

Timotius, S., Idirs, and M. Syahrir. 2009. A review on ornamental coral farming effort in Indonesia. The International Ocean Science, Technology and Policy Symposium, World Ocean Conference. $11 \mathrm{p}$.

Turak, E., C. Sheppard, and E. Wood. 2008. IUCN red list of threatened species. 
http://www.iucnredlist.org/ [Accessed 11 May 2015].

UNEP WCMC. 2009. Review of species selected on the basis of a new or increased export quota in 2009. Prepared for the European Commission, Directorate General E-Environment, ENV.E.2-Development and Environment. 36p.
Wood, E., K. Malsch, J. Miller. 2012. International trade in hard corals: review of management, sustainability and trends. Proc. Of the $12^{\text {th }}$ International Coral Reef Symposium, Cairns, Australia. 5p.

Diterima: 3 November 2015

Direview: 3 November 2015

Disetujui: 6 Desember 2015 